\title{
Molecular Identification and Disease Management of Date Palm Sudden Decline Syndrome in the United Arab Emirates
}

\author{
Khawla J. Alwahshi ${ }^{1}$, Esam Eldin Saeed ${ }^{2}$, Arjun Sham ${ }^{1}{ }^{1}$, Aisha A. Alblooshi ${ }^{1}$, \\ Marwa M. Alblooshi ${ }^{1}$, Khaled A. El-Tarabily ${ }^{1,3, *}$ and Synan F. AbuQamar ${ }^{1, *}$ \\ 1 Department of Biology, United Arab Emirates University, Al Ain 15551, UAE; 200413061@uaeu.ac.ae (K.J.A.); \\ arjunsham@uaeu.ac.ae (A.S.); 201110117@uaeu.ac.ae (A.A.A.); 201416798@uaeu.ac.ae (M.M.A.) \\ 2 Khalifa Center for Genetic Engineering and Biotechnology, United Arab Emirates University, Al Ain 15551, \\ UAE; esameldin_saeed@uaeu.ac.ae \\ 3 School of Veterinary and Life Sciences, Murdoch University, Murdoch, Western Australia 6150, Australia \\ * Correspondence: ktarabily@uaeu.ac.ae (K.A.E.-T.); sabuqamar@uaeu.ac.ae (S.F.A.); \\ Tel.: +971-3-713-6518 (K.A.E.-T.); +971-3-713-6733 (S.F.A.)
}

Received: 2 January 2019; Accepted: 17 February 2019; Published: 20 February 2019

\begin{abstract}
Date palm orchards suffer from serious diseases, including sudden decline syndrome (SDS). External symptoms were characterized by whitening on one side of the rachis, progressing from the base to the apex of the leaf until the whole leaf dies; while the internal disease symptoms included reddish roots and highly colored vascular bundles causing wilting and death of the tree. Although three Fusarium spp. (F. oxysporum, F. proliferatum and F. solani) were isolated from diseased root samples, the fungal pathogen F. solani was associated with SDS on date palm in the United Arab Emirates (UAE). Fusarium spp. were identified based on their cultural and morphological characteristics. The internal transcribed spacer regions and large subunit of the ribosomal RNA (ITS/LSU rRNA) gene complex of the pathogens was further sequenced. Pathogenicity assays and disease severity indices confirm the main causal agent of SDS on date palm in the UAE is F. solani. Application of Cidely ${ }^{\circledR}$ Top (difenoconazole and cyflufenamid) significantly inhibited the fungal mycelial growth in vitro and reduced SDS development on date palm seedlings pre-inoculated with F. solani under greenhouse conditions. This is the first report confirming that the chemical fungicide Cidely ${ }^{\circledR}$ Top is strongly effective against SDS on date palm.
\end{abstract}

Keywords: date palm; disease management; Fusarium solani; pathogenicity; sudden decline syndrome; UAE

\section{Introduction}

Date palm (Phoenix dactylifera L.) is an economically important crop that is mainly cultivated in tropical and subtropical regions. Date palm fruits possess high nutritional and therapeutic values with significant antioxidant, antiproliferative, and antimicrobial properties [1]. Traditionally, date palm is cultivated in the Arabian Peninsula including the United Arab Emirates (UAE), which is now one of the top 10 producers of date palm worldwide [2]. The UAE produced 825,300 and 671,891 tons of dates in 2010 and 2016, respectively, which represents a decrease of $18 \%$ in the production levels. This can be attributed to increasing production costs, unfavorable climatic changes, and disease pressures. Despite the decline in production, the increasing demand for date palm still outweighs the annual yield, making the UAE a leading producing and exporting country of dates. Therefore, it is vital to address the ongoing threats to date palm production in the UAE and around the world. 
Fungi are known as the most causal agents of diseases on date palm trees [3]. Black scorch and sudden decline syndrome (SDS; also known as Fusarium wilt) are among the devastating diseases of date palm. In the UAE, the soil-borne fungal pathogen Thielaviopsis punctulata was found few years back to cause black scorch disease on date palm [4]. On the other hand, the causal agent of SDS remained uncertain for many years due to different Fusarium spp. associated with it, or mixing the symptoms with other wilt diseases. For example, 10 fungal species were associated with date palm roots that may infect date palm trees individually or in combinations to cause diseases in the UAE [5]. Although SDS has been reported to negatively affect date palm plantations, the causal agent of this disease is still ambiguous and disputed amongst researchers in the UAE and elsewhere. Fusarium classification and nomenclature system has gone through its unsteadily transformation; and consequently, researchers have not been able to come to a consensus on which Fusarium spp. is the appropriate forma specialis (f. sp.) for SDS pathogen. There are several studies that suggest Fusarium oxysporum, F. moniliforme, F. proliferatum, and F. solani to be associated with SDS in different parts of the world [6-11]. The vascular fusariosis, commonly known as Bayoud, caused by F. oxysporum $\mathrm{f}$. sp. albedinis is the most destructive fungal disease of date palm in North Africa particularly Algeria, Morocco and Mauritania [12,13]. Bayoud, however, has never been reported in the UAE or any country of the Arabian Peninsula.

Despite having different Fusarium spp. linked with disease symptoms, SDS causes the most damage in date palm plants that live in warm, dry regions [14]. Fusarium spp. are soil-borne vascular wilt pathogens, and disease cycles of most Fusarium wilts can be divided into dormant, parasitic and saprophytic stages [15]. The dormant stage comprises inhibition and germination of resting structures in soil. The parasitic stage comprises penetration of roots, colonization of the root cortex and endodermis, movement to the xylem; colonization of the xylem tissues of stems and leaves, symptom expression and, finally, death of the host. The saprophytic stage is the formation of resting structures in the dead host [14]. Plants growing in cooler, wetter areas still show symptoms but in slower rates. This disease is contagious and may infect other trees nearby. In general, the fungus causing SDS in plants can persist in soil for several years without a susceptible host. Spores often enter plants through roots and are transported to the rest of plant tissues through the vascular system [9]. The pathogen attacks the xylem, reducing water uptake and the tree gradually shows signs of water scarcity. The pathogen can also spread through mechanical means e.g., pruning tools, or contaminated seedlings from unsanitary nurseries $[15,16]$. In general, SDS can be recognizable by similar symptoms on most cultivars of date palm [17]. Due to limitation in water transport in vascular tissues, fronds, or leaves of the tree are the first to display signs of infection. The opportunistic fungus usually attacks old, weak, or injured plants. Depending on the severity of the disease, initial symptoms occur on the lowest outer leaves of the middle crown, and discoloration of leaves from pale green to yellow usually starts at the base of the palm fronds and moves upwards [18]. When disease progresses, leaves turn white on one side before developing on the other side of the leaf. This is associated with crinkling at the ends of leaflets, and finally leaves dry and eventually die. The dying process may take a few days to several weeks. Similar symptoms will re-appear on other younger leaves. Once the symptoms of decline are clearly seen, it is difficult to reverse the progress of the disease. So far, SDS has no cure for date palm.

On the other hand, careful management programs and good horticultural practices may reduce the pathogen impacts and extend the life of the tree [19]. Such practices can include pruning the infected parts and burning the symptomatic fronds. Since many fungal pathogens invade host tissues through mechanical injury or natural openings, wounds should be avoided. Regular maintenance and proper fertilization are also recommended to increase the health and vigor of date palm trees [20]. Yet, the use of chemicals continues to be the major strategy to mitigate the menace of crop diseases, regardless of its ecological problems and public health concerns. Foliar applications with benzimidazole- or copper-based fungicides can reduce SDS incidence at early stages of infection [21,22]. Except for a few cases, biological control agents (BCAs) such as Trichoderma spp. is not sufficiently effective against 
Fusarium spp. in date palm [21]. Therefore, minimum chemical fungicide application can be used. Thus, integrated disease management (IDM) programs can be implemented to manage SDS which combine cultural, chemical and biological control with resistant cultivars of date palm [23]. Our aim in this study was to isolate, identify the Fusarium spp. and evaluate the efficacy of available fungicides to protect seedlings of date palm from SDS. This research shed more light on this critical disease and how the pathogen is able to produce such devastating outcomes on date palm trees. We reported the evaluation of systemic chemical fungicide treatments against $F$. solani in the greenhouse as a reliable approach to reduce the economic losses associated with SDS. Future research on the disease agent and its ability to cause damage and spread on date trees will further assist in the development of effective IDM strategies to manage this disease.

\section{Results}

\subsection{Symptoms of SDS on Date Palm}

Symptoms of SDS were noticed on manifested date palm trees from Al Wagan, Al Ain, UAE (Figure 1A). Although the pathogen was observed to attack different parts of the date palm trees, plant tissues were severely affected. The symptoms started with orange yellowish coloring for the rachis (frond's midrib), followed by the leaflets (pinnae). This disease usually progresses from outer frond whorls toward central younger fronds, and from base to apex (Figure 1B). In general, drying begins from the terminal part in a single frond to cover the whole frond (Figure 1C). The affected leaves turn pale green and then to a yellowish color. The discoloration continues outward and the color becomes white on one side of the frond until the whole leaf is completely white (Figure 1C).

A

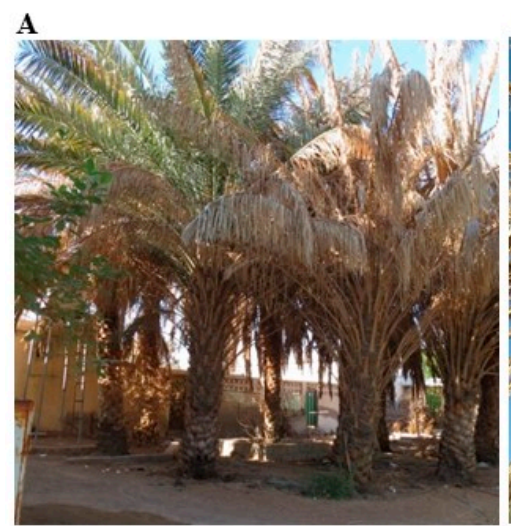

D

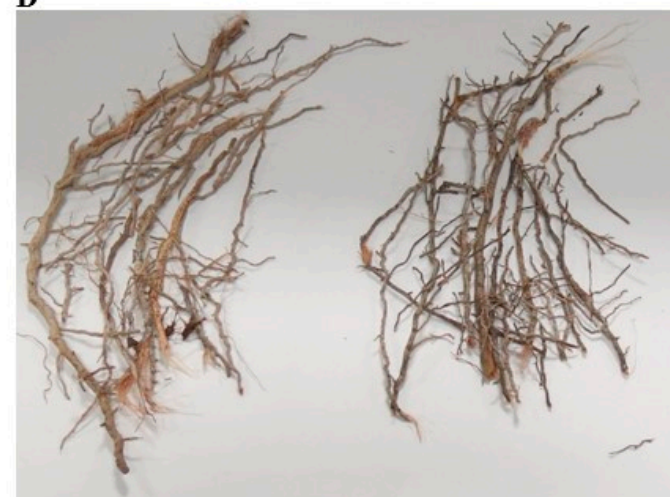

B
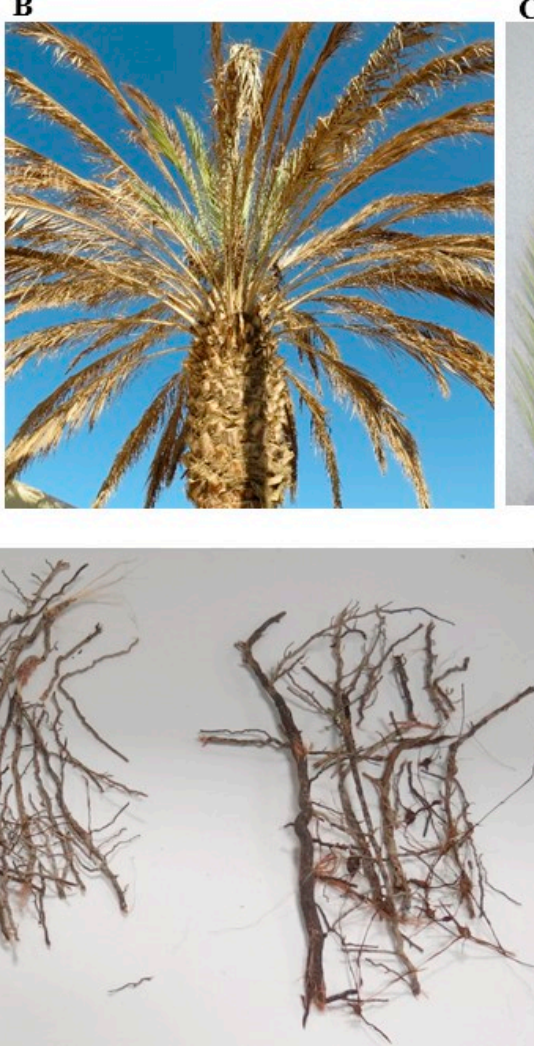

C

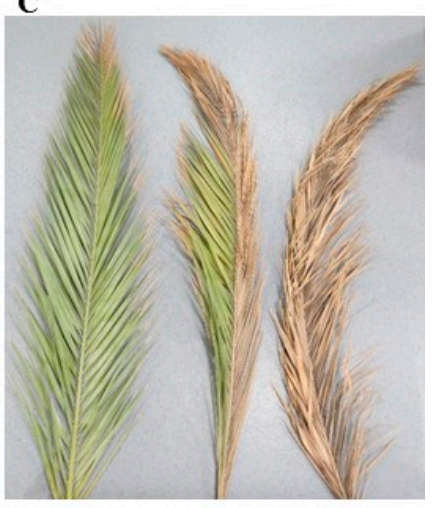

E

F

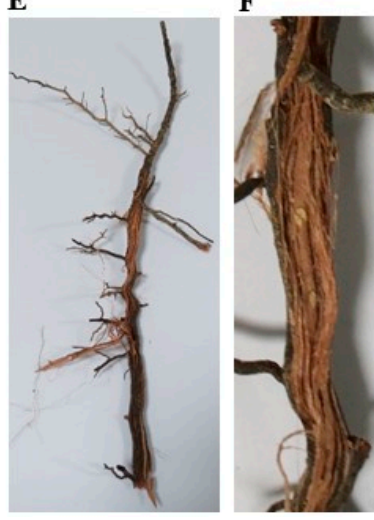

Figure 1. Date palm trees showing symptoms of sudden decline syndrome. Symptoms on a group of trees (A); and whole tree (B) of date palm. Progress of symptoms on fronds (C) and roots (D) of diseased plants. Brown-colored, dry roots (E); and redness of vascular tissues $(\mathbf{F})$. In (A-F), naturally infested date trees with Fusarium spp. 
Under severe conditions, roots show reddish color (Figure 1D,E), fronds start drying up and the terminal bud is affected. In most cases, external symptoms are usually associated with highly colored vascular bundles (Figure 1F). Eventually, the entire tree dies within few months. Similar symptoms of decline then begin to appear on other leaves and pinnae. Thus, all palms are rarely found infected in an orchard at same time (Figure 1A). These symptoms on date palm are typical of the SDS that is known to be caused by a soil-borne fungus Fusarium spp.

\subsection{Cultural and Morphological Identification of Fusaium spp. Associated with SDS}

We microscopically examined the sporulation of the isolated pathogens from affected tissues on potato dextrose agar (PDA) plates. Based on the color of colonies and conidial morphology identified on PDA, we predicted that the culture of the identified isolates may belong to Fusarium spp. Colonies of the first isolate were woolly to cottony with cream to white aerial mycelium and purple pigment (Figure 2A; Figure S1). We also observed mycelial growth and production of microconidia and macroconidia. Conidiophores had simple or branched monophialides (Figure 2B). Microconidia are generally small, 1-2 celled, hyaline with oval to oblong or reniform with slightly curved shape, measuring 9.2-11.8 $\times 3.3-4.8 \mu \mathrm{m}$ (Figure 2C). On the other hand, macroconidia have 3-5 septa, and are boat-shaped to oblong and 28.0-30.5 $\times 3.5-5.3 \mu \mathrm{m}$ in size. Together, this suggests that this fungal isolate could be F. oxysporum f. sp. cumini (Prasad \& Patel) [24].

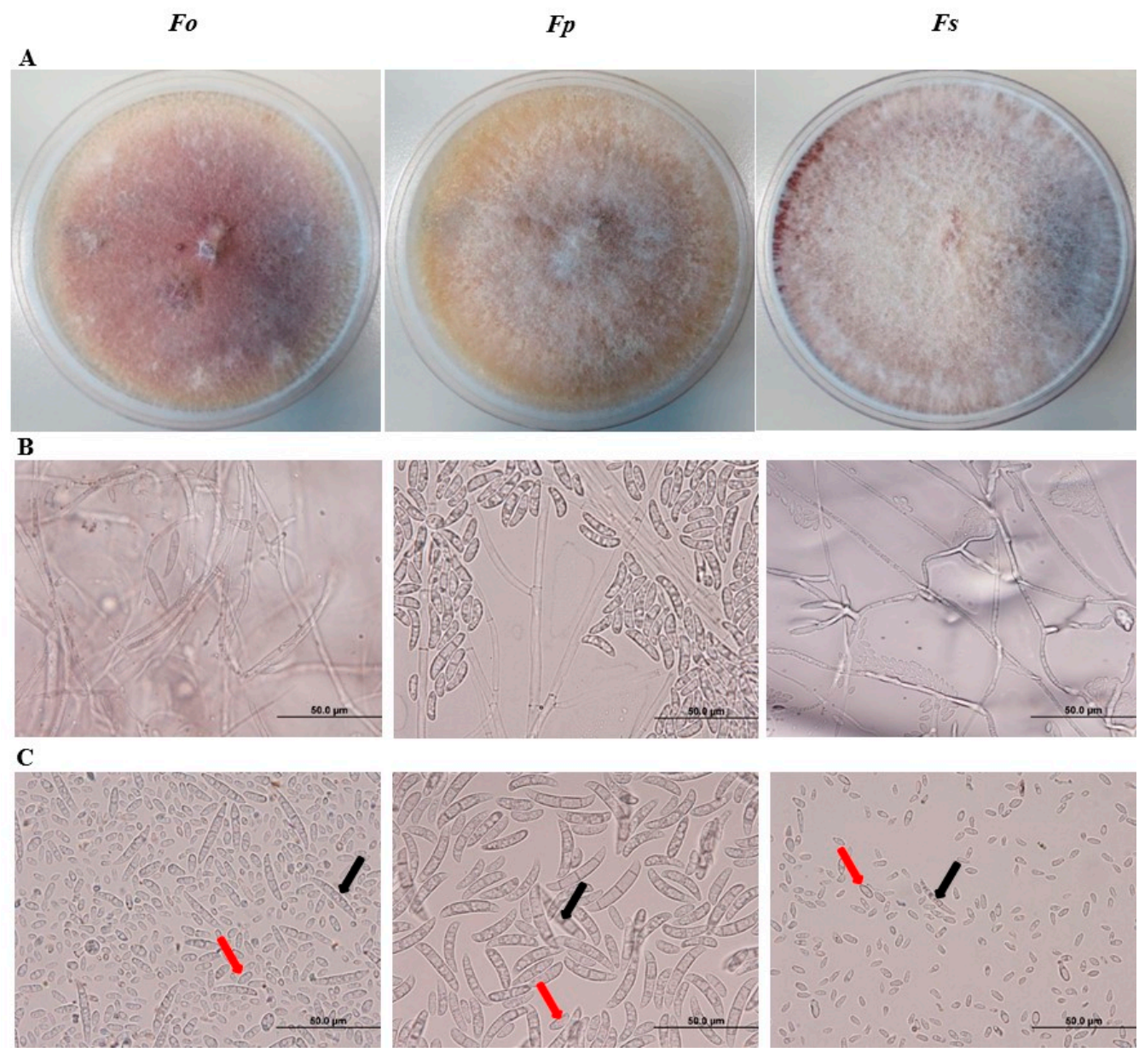

Figure 2. Morphological phenotypes mycelium and conidia of Fusarium spp. Mycelia of Fusarium spp. growing on a 10-day old PDA culture plate (A). Mycelium growth (B); and microconidia (red arrow) and macroconidia (black arrow) (C) of Fusarium spp. In (A-C), mycelia and conidia are from a 10-day old PDA culture. Fo, F. oxysporum; Fp, F. proliferatum; Fs, F. solani. 
We also isolated F. proliferatum (Matsushima) Nirenberg [25]. On PDA, colonies grew rapidly, aerial mycelia were white to dark vineaceous or purple (Figure 2A; Figure S1). Conidiophores were densely branched arising laterally from aerial hyphae (Figure 2B). Although chlamydospores were absent, macroconidia were distinctly abundant (Figure 2C). The 3-5 septated, nearly straight macroconidia had a size of $25.0-56.6 \times 2.6-4.6 \mu \mathrm{m}$. Microconidia were clavate measuring $2.2-3.0 \times 6.8-8.6 \mu \mathrm{m}$.

Colonies on PDA of the third isolate were fast-growing with white and purple, fluffy aerial mycelia with undersurface showing a dark violet color (Figure 2A; Figure S1). Hyphae were septate and hyaline; conidiophores were unbranched (Figure $2 \mathrm{~B}$ ). The produced microconidia were thin walled, hyaline, and oval to kidney-shaped, and were measured 10.8-15.4 $\times 2.0-4.0 \mu \mathrm{m}$ (Figure 2C). Macroconidia had 3-5 septa with 24.6-44.2 $\times 3.2-4.2 \mu \mathrm{m}$, with stout and falcate (curved) shaping. We speculate that $F$. solani (Martius) Saccardo [26] was one of the fungal pathogens isolated from root tissues of SDS symptomatic date palm trees. Our cultural and morphological analyses suggest that Fusarium spp. caused SDS. Thus, molecular identification on an isolated specimen would remove any kind of controversial identification at the species level.

\subsection{Molecular and Phylogenetic Classification of Fusarium spp.}

We established a phylogenic analysis on the isolates obtained in this study. To identify the fungi generated from the infected tissues (Figure 2), DNA isolated from the PDA-grown mycelium of each sample was PCR amplified. Successful amplification with primer targeted to the genomic regions of internal transcribed spacer (ITS), $28 \mathrm{~S}$ rDNA region and translational elongation factor 1- $\alpha$ (TEF1- $\alpha$ ) was obtained from all putative Fusarium spp., and also the amplification product of $\beta$-tubulin gene was visible in putative F. solani and F. oxysporum specimens (Figure 3A). This confirms that Fusarium spp. are the pathogens frequently associated with all SDS symptoms on date palm trees. Until this report, no DNA sequences of the species collected in the UAE were available in GenBank. Therefore, the ITS rDNA and TEF1- $\alpha$ genes [27] were further sequenced and deposited in GenBank: F. oxysporum ITS/LSU rDNA (MH055398) and TEF1- $\alpha$ (MH087478), F. proliferatum ITS/LSU rDNA (MH055399) TEF1- $\alpha$ (MH087479), and F. solani ITS/LSU rDNA (MH055400) and TEF1- $\alpha$ (MH087480). We also tried to amplify the flanking DNA regions of the Fot1 insertion sites of the pathogen F. oxysporum $\mathrm{f}$. sp. albedinis from these samples. By using pFalb11 and pFalb28 primer pairs [28], none of the samples used in the PCR assays thus provide evidence of any diagnosis for F. oxysporum $\mathrm{f}$. sp. albedinis isolates in the UAE (Figure S2).

In addition, the molecular analysis of combined sequence data of ITS regions and TEF-1 $\alpha$ was used to determine the relationship among the obtained Fusarium spp. and other closely related ITS / TEF1- $\alpha$ sequences for the generation of the phylogenetic tree [29,30]. For the estimation of the phylogenetic tree, sequences were aligned and maximum likelihood (ML) analyses were performed. The adaptation to different plant hosts has led to the evolution of over 30 cryptic species within the Fusarium spp. complex [12]. The generated ITS/TEF1- $\alpha$ sequence belonging to the isolated strains clustered separately representing three different clades corresponding to F. oxysporum, F. proliferatum and F. solani from different sources (Figure 3B). Phylogenetic tree analysis demonstrated that three strains isolated from the UAE were placed in F. oxysporum, F. Proliferatum, and F. solani groups with a strong bootstrap support (100, 93, and 100\%, respectively). This confirms the identity of these isolates with Fusarium spp. Among the studied species, our analysis revealed that our isolates $F$. oxysporum DSM 106834, F. proliferatum DSM 106835 and F. solani DSM 106836 had a sister relationship with F. oxysporum NRRL 52741, F. proliferatum NRRL 25091 and F. solani NRRL 52704, respectively, which distinguishes the obtained isolates from those belonging to other Fusarium or Nectriaceae spp. Our phylogenetic analysis supports that F. oxysporum DSM 106834, F. proliferatum DSM 106835 and $F$. solani DSM 106836 dominate in the UAE. Altogether, this suggests that at least one of the Fusarium isolates is probably the causal species of SDS on date palm. 
$\mathbf{A}$

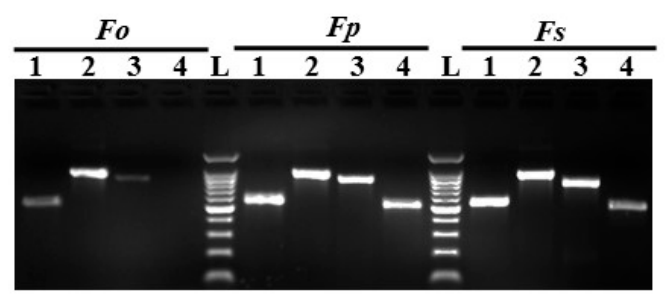

B

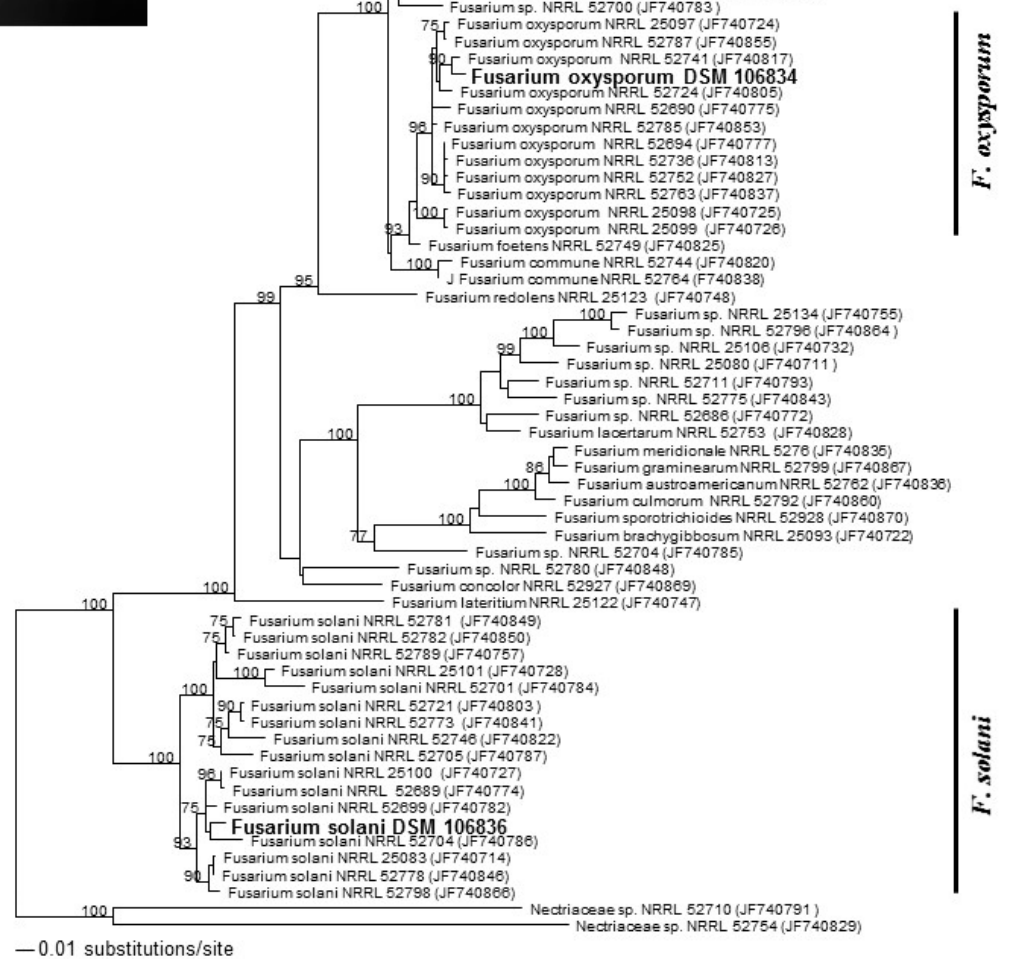

Figure 3. Identification of Fusarium spp. at the molecular level. PCR amplification of specific genomic DNA regions of infected root tissues (A); and dendrogram showing phylogenetic relationships among F. oxysoprum (Fo) species complex (DSM 106834), F. proliferatum (Fp) (DSM 106835), and F. solani (Fs) species complex (DSM 106836) identified in this study and other members of Fusarium spp. prepared by the maximum likelihood (ML) method (B). In (A), lanes 1-4 correspond to amplifications of ITS, 28S rDNA region, TEF1- $\alpha$ and $\beta$-tubulin in roots. In (B), the ML tree was obtained from combined ITS/LSU rDNA and TEF $\alpha-1$ sequence data. The specimens used in this study carry GenBank accession numbers, Fo ITS/LSU rDNA (MH055398), Fo TEF1- $\alpha$ (MH087478), Fp ITS/LSU rDNA (MH055399), Fp TEF1- $\alpha$ (MH087479), Fs ITS/LSU rDNA (MH055400), Fs TEF1- $\alpha$ (MH087480). Numbers at the nodes are ML bootstrap values after 100 replicates are expressed as percentages $(\mathrm{LnL}=-8908.252933)$. The scale bar on the rooted tree indicates a 0.01 substitution per nucleotide position. The strains from this report are indicated in bold. Nectriaceae spp. NRRL 52710 (JF740791) and NRRL 52754 (JF740829) were used as outgroups. ITS, internal transcribed spacer; $28 \mathrm{~S}$ rDNA, large subunit (LSU) of rDNA; TEF1- $\alpha$, translational elongation factor $1-\alpha$; L, DNA ladder.

\subsection{Pathogenicity Tests of Fusarium spp. on Date Palm Seedlings}

To confirm our results, pathogenicity tests using individual and combined isolated pathogens on healthy date palm seedlings (cv. Barhi) were performed and monitored for disease progress. Plants were inoculated with the conidial suspension in the root system using a 10-day old pure culture of F. oxysporum, F. proliferatum, or F. solani grown in PDA, while control seedlings were inoculated with sterile distilled water. We also treated the roots with the three combined conidial suspensions to determine whether SDS symptoms on date palm seedlings are similar to or stronger than in 
inoculations of individual Fusarium spp. under greenhouse conditions. Following inoculation with F. oxysporum or F. proliferatum, seedlings did not develop SDS symptoms on stem and leaf tissues (Figure 4A). However, typical symptoms of SDS such as white color and dryness of the stem and leaves appeared at 10 days post inoculation (dpi) with F. solani. Moreover, the disease progressed rapidly along the stem and leaves in the following days. At $35 \mathrm{dpi}$, symptoms often expressed as complete dryness of leaves and characterized by tissue necrosis in F. solani-inoculated plants (Figure 4A,B). Minor effect on seedlings inoculated with any of the other two Fusarium spp. was observed after 35 days. Similar to $F$. solani-inoculation, symptoms developed quickly and seedlings showed complete discoloration and necrosis of tissues by the end of the experiment when the three species of Fusarium were combined (Figure 4A,B). Control leaf tissues remained symptomless. To fulfill Koch's postulates, the pathogens were consistently re-isolated from the disease affected tissues; thus, detected symptoms were associated with the inoculation with the pathogen F. solani (Figure 4C).

A
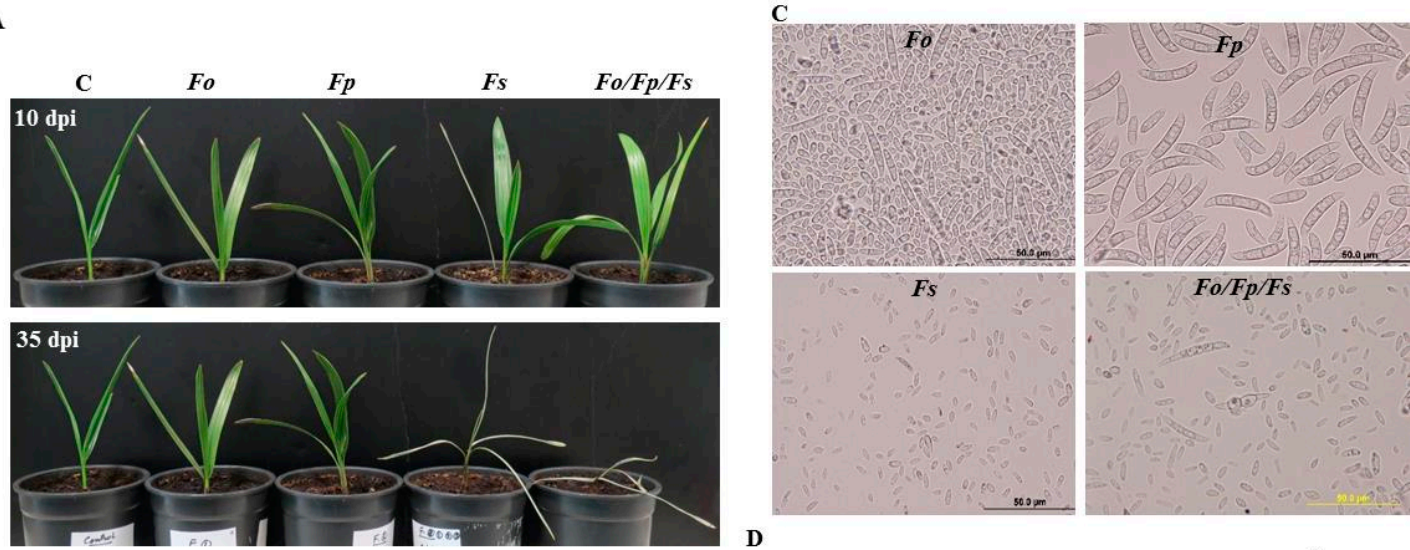

B
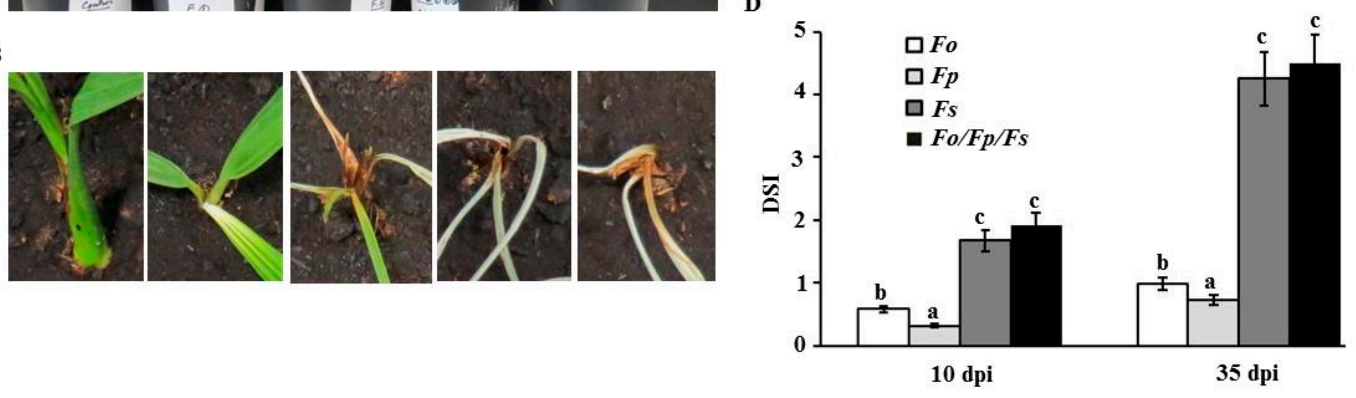

Figure 4. Pathogenicity and Koch's postulate testing with Fusarium spp. Pathogenicity test on inoculated and non-inoculated date palm seedlings cv. Barhi at $10 \mathrm{dpi}$ (top) and $35 \mathrm{dpi}$ (bottom) (A); symptomatic tissues of the inoculated area of the seedling at $35 \mathrm{dpi}$ (B); conidia after re-isolation of the pathogen from colonized tissues at $35 \mathrm{dpi}(\mathrm{C})$; and disease severity index (DSI) of affected seedlings $(n=12)$ at 10 and $35 \mathrm{dpi}(\mathbf{D})$. In (B), close-up views of infected stem and frond at $35 \mathrm{dpi}$ of Fusarium-inoculated and non-inoculated seedlings. Young seedlings showing general whitening and dryness of stem and leaf tissues in F. solani and the three Fusarium spp. In (D), DSI is on a scale of 5: $0=$ no infection, $1=1-10 \%, 2=11-25 \%, 3=26-50 \%, 4=51-75 \%$, and $5=76-100 \%$ damage including necrosis, white area in leaves or rotting in roots. Values with different letters are significantly different from each other at $p=0.05$. C, control (no infection); Fo, F. oxysporum; Fp, F. proliferatum; Fs, F. solani; Fo/Fp/Fs, all three Fusarium spp.; dpi, days post inoculation.

Based on visual observations (Figure 4A), we speculated that the three combined Fusraium spp. might have a synergetic effect on date palm seedlings. Disease severity index (DSI) on date palm seedlings inoculated with the three Fusarium spp. was not significantly different from those inoculated with F. solani throughout the greenhouse experiment (Figure 4D). However, pathogenic ability of $F$. oxysporum or F. proliferatum had less effect on the seedlings. This is evident from DSI which predicted reduced scores of affected seedlings of date palm with F. oxysporum or F. proliferatum when compared 
with that of F. solani or the combinations of Fusarium spp. at 10 and 35 dpi. Our data suggest that $F$. solani causes the disease on different tested tissues of date palm.

\subsection{In Vitro Evaluation of Selected Fungicides against Fusarium spp.}

We evaluated the effect of Baiclean ${ }^{\circledR}$ (Oligosaccharin), Uniform ${ }^{\circledR}$ (Azoxystrobin and Metalaxyl-M) and Cidely ${ }^{\circledR}$ Top (Difenoconazole and Cyflufenamid) fungicides on the mycelial growth of the three Fusarium spp. in vitro. In PDA plates, a final concentration of 0, 25, 75, 125, 250, 500, and 1000 ppm of the selected fungicides were applied (Figure S3). Interestingly, mycelial growth increased in all isolates at higher concentrations of the fungicide Baiclean ${ }^{\circledR}(>250 \mathrm{ppm})$ compared with lower concentrations $(<250 \mathrm{ppm})$. When different concentrations of Uniform ${ }^{\circledR}$ fungicide were applied, we noticed similar or minimal effect on the mycelial growth of the three fungal strains (Figure S3). On the other hand, Cidely ${ }^{\circledR}$ Top showed the highest mycelial growth inhibition on Fusarium spp. at all tested concentrations in vitro. Accordingly, the concentration of $250 \mathrm{ppm}$ in the selected fungicides was further used and was considered as the most efficient concentration in the three fungicides (Figure 5A).

$\mathbf{A}$

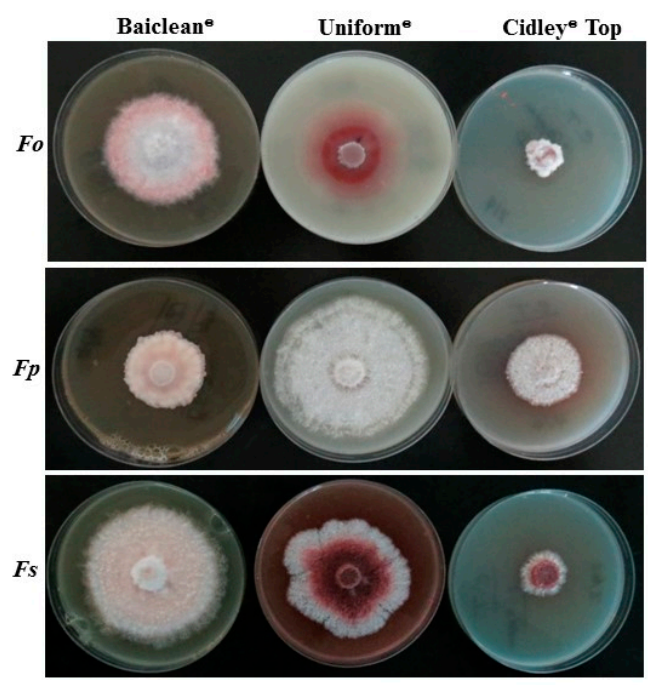

B

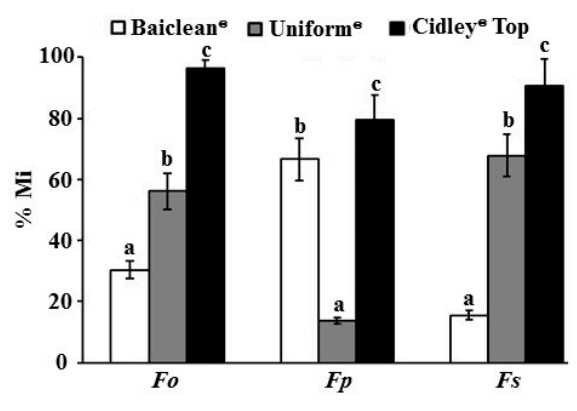

C

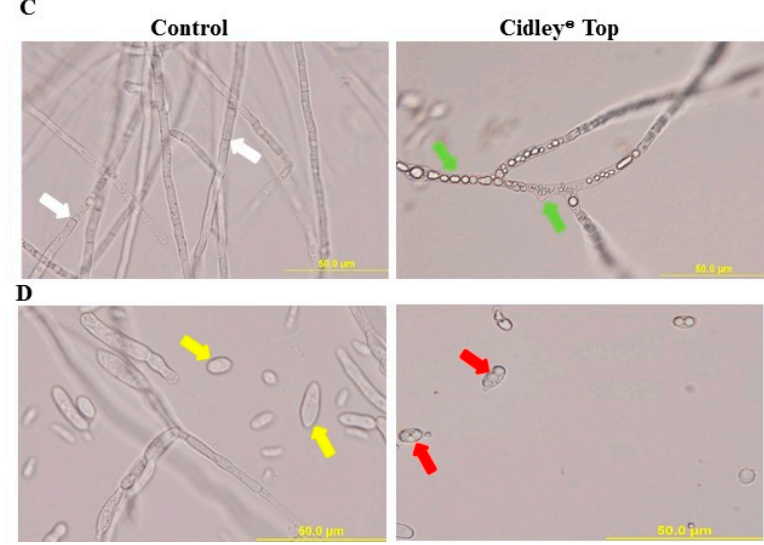

Figure 5. Efficacy of fungicides against Fusarium spp. in vitro. Effect of fungicides ( $250 \mathrm{ppm}$ ) on in vitro mycelial growth (A); growth inhibition rate (\% Mi) of Fusarium spp. using $250 \mathrm{ppm}$ of the fungicides after 10 days (B). Abnormalities in hyphal morphology, septum formation and cytoplasmic contents (C); and deformation of conidia (D) of F. solani following Cidely ${ }^{\circledR}$ Top treatment compared to control. In (B), values with different letters are significantly different from each other at $p=0.05$; In (C), white arrows indicate normal septate hyphal growth; and green arrows indicate formation of non-septate hyphal formation and cytoplasmic coagulation. In (D), yellow arrows indicate normal formation of conidia; and red arrows indicate deformation of conidia. Fo, F. oxysporum; Fp, F. proliferatum; Fs, F. solani.

At $250 \mathrm{ppm}$, three fungicides were statistically evaluated for their effectiveness to inhibit the growth of three potential isolates of Fusarium spp. of proven pathogenicity to date palm in vitro. After 10 days of inoculation, mycelial growth inhibition rate (\% Mi) of F. oxysporum, F. proliferatum, and F. solani were significantly different among the three tested fungicides at $250 \mathrm{ppm}$ (Figure 5B). Thus, Cidely ${ }^{\circledR}$ Top fungicide increased fungal mycelial growth inhibition at $250 \mathrm{ppm}$ and showed the highest zone of inhibition, ranging between $79.5-96.3 \%$ (Figure 5A,B). This suggests that the systemic 
fungicide, Cidely ${ }^{\circledR}$ Top, inhibited the mycelial growth of Fusarium spp. and that 250 ppm is the recommended dosage of this fungicide to further applied in the greenhouse experiment.

Due to the pathogenicity of $F$. solani on date palm under greenhouse conditions (Figure 4 ) and the effectiveness of $250 \mathrm{ppm}$ of Cidely ${ }^{\circledR}$ Top in vitro (Figure 5), a microscopic examination was performed to find out the mode of action of this fungicide in inhibiting the growth of this pathogen. Our results revealed that Cidely ${ }^{\circledR}$ Top caused significant morphological alternations in F. solani. When Cidely ${ }^{\circledR}$ Top was applied, we observed unusual morphological abnormalities in cultures of $F$. solan $i$ in comparison to control (no fungicide) treatment. The fungicide not only caused septal malformations and cytoplasmic coagulation in the hyphal cells (Figure 5C), but also conidial deformation in F. solani (Figure 5D). Altogether, Cidely ${ }^{\circledR}$ Top inhibited the mycelial growth and induced morphological abnormalities of $F$. solani DSM 106836. There are several cases of chemical control of plant pathogens successfully reported under laboratory conditions, but when repeated at a greenhouse-scale, they fail to have the predicted impact [31].

\subsection{Effect of Cidely ${ }^{\circledR}$ Top on Date Palm Seedlings Infected with F. solani}

In the greenhouse experiments, we measured the efficacy of the most promising fungicide, Cidely ${ }^{\circledR}$ Top, at 7 and 25 days post treatment (dpt) on diseased date palm plants. We first inoculated seedlings with the fungal pathogen, F. solani, for 10 days until plants showed visible symptoms of SDS; followed by a treatment with Cidely ${ }^{\circledR}$ Top on diseased seedlings (designated as $0 \mathrm{dpt}$ ). At $7 \mathrm{dpt}$ with the fungicide, plants started to recover and prevented further disease progression at the end of the assessment period of $25 \mathrm{dpt}$ (Figure 6A). This was in contrast to diseased plants that were sprayed with water (F. solani). Affected plants that were treated with Cidely ${ }^{\circledR}$ Top clearly showed vegetative growth recovery (Figure 6A) and developed healthy root system (Figure 6B) at $25 \mathrm{dpt}$ comparable to control plants with no prior artificial infection.

We also determined the effects of the chemical fungicide, Cidely ${ }^{\circledR}$ Top, on the number of conidia progressing on diseased seedlings. As expected, a steep drop in the number of conidia was remarked in Cidely ${ }^{\circledR}$ Top-treated seedlings (Figure 6C). In general, the number of conidia of F. solani recovered from the roots of treated-date palm plants was at least 20-fold reduced when compared with that in untreated ones. Based on the level of severity of necrosis in leaves or rotting in roots, DSI was also assessed on diseased- and recovered-seedlings (Figure 6D). It is evident from our results that seedlings treated with Cidely ${ }^{\circledR}$ Top fungicide had significantly lower DSI than inoculated-seedlings but without fungicide treatment at the same period of assessment $(7$ and $25 \mathrm{dpt})$. Together, this suggests that $F$. solani appeared to lose some of its aggressiveness as a pathogen and the severity of SDS was gradually suppressed as a disease when Cidely ${ }^{\circledR}$ Top fungicide was applied on date palm plants. 


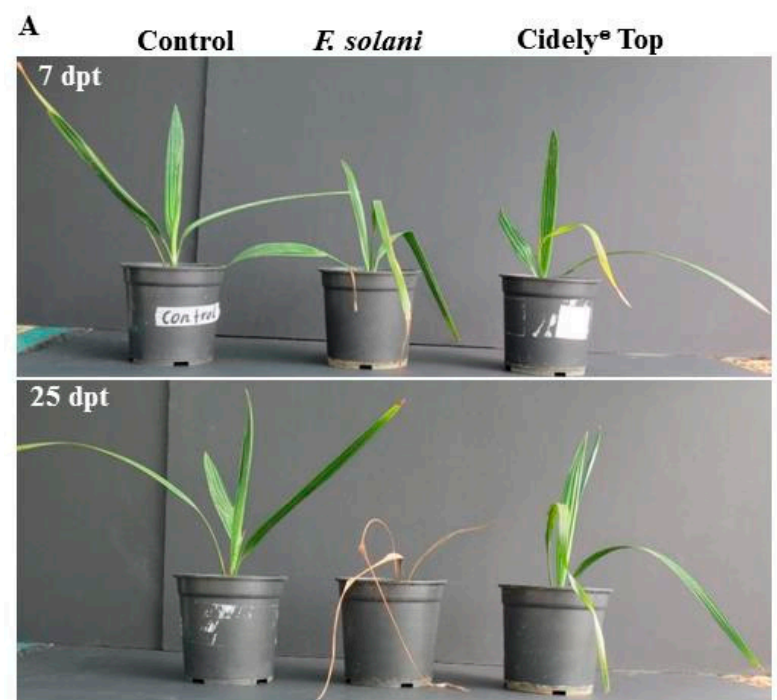

B

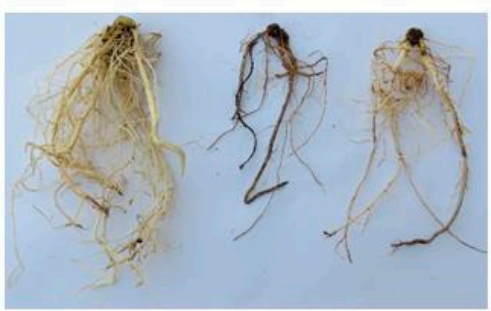

C

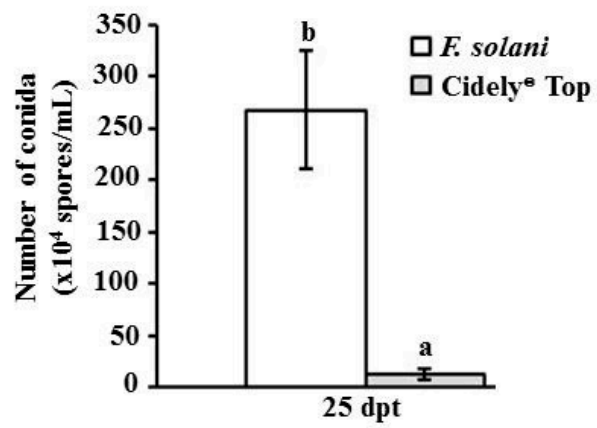

D

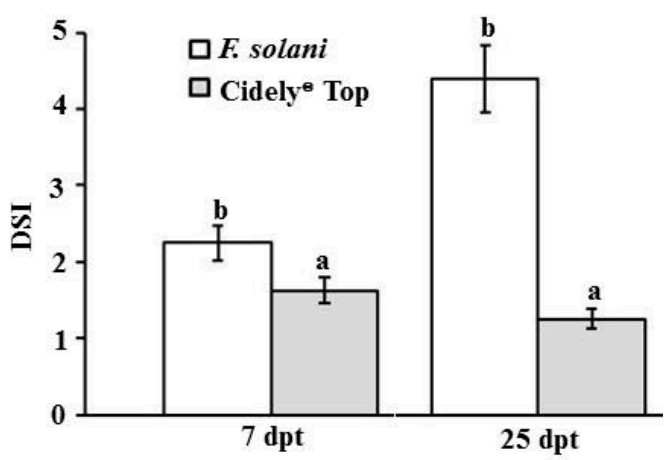

Figure 6. Effect of fungicide treatments on artificially inoculated date palm seedlings with $F$. solani in the greenhouse. Fungicidal suppression of Fusarium wilt disease on date palm seedlings cv. Barhi using Cidely ${ }^{\circledR}$ Top fungicide at 7 (top panel) and 25 (bottom panel) dpt (A); recovery of root tissues previously infected with $F$. solani using $250 \mathrm{ppm}$ of Cidely ${ }^{\circledR}$ Top fungicide after $25 \mathrm{dpt}$ (B). Number of conidia $\left(\times 10^{4}\right.$ spores $\left./ \mathrm{mL}\right)(\mathrm{C})$ and disease severity index (DSI) (D) after the application of Cidely ${ }^{\circledR}$ Top on date palm seedlings infected with F. solani $(n=12)$. In (D), DSI is on a scale of 5: $0=$ no infection, $1=1-10 \%$, $2=11-25 \%, 3=26-50 \%, 4=51-75 \%$, and $5=76-100 \%$ damage including necrosis, white area in leaves or rotting in roots. In (C-D) Values with different letters are significantly different from each other at $p=0.05$. In (A-D), seedlings inoculated with F. solani at 10 days before the fungicide treatment. Control, non-inoculated seedling; F. solani, infected seedlings with F. solani only; Cidely ${ }^{\circledR}$ Top, infected seedlings with $F$. solani and sprayed with Cidely ${ }^{\circledR}$ Top; dpt, days post treatment.

\section{Discussion}

Date palm (Phoenix dactylifera L.) is an important and economic fruit crop in the tropical and subtropical areas and is widely grown in the UAE. Diseases, including those caused by fungal pathogens, are among the major factors that affect marketing and hinder the yield of dates [32]. Under local conditions of the UAE, roots of date palm are liable to attack by several pathogenic soil-borne fungi that cause destructive diseases such decline, wilt, neck bending and root rot $[4,5]$. Recent studies have linked these diseases with F. solani, Lasiodiplodia theobromae, L. hormozganensis, Thielaviopsis punctulate, and T. paradoxa being the most common in the UAE [4,5,33]. In the UAE, farmers might be confused between disease symptoms of black scorch and SDS on date palm. Symptoms of black scorch disease are hard black lesions on leaves, inflorescence blight, and trunk rot [4,32]. Death of trees occurs from tips or terminal buds back inwards. Typical disease symptoms of SDS in the UAE are the orange-yellowish fronds, and the drying of leaflets. In contrast to black scorch, drying usually starts from older, lower fronds toward younger, central fronds. Regrettably, the end result of untreated palm trees is death within few months in both cases.

Although several fungi have been recorded as causal pathogens of SDS on date palm worldwide $[9,21,34,35]$, many of these studies have reported the isolation of Fusarium spp. from roots, 
fronds, and trunks of date palm trees showing wilt and decline [21,22]. For example, F. oxysporum, F. proliferatum, and $F$. solani have been most frequently found in roots displaying decline symptoms on date palm in different regions of Iraq $[8,36]$. In Egypt, declined date palm trees have been associated with two Fusarium spp., F. solani and F. monliforme [37]. A serious disease of yellowing and death of the fronds in date palm groves in Iran has also been reported to be caused by F. solani [9]. Three Fusarium spp. have been isolated from the infected fronds and roots of date palm trees, and have been identified as F. oxysporum, F. proliferatum, and F. solani in Saudi Arabia, particularly in Al Qassim and Al-Medina Al-Monawara regions [6]. In the $\mathrm{UAE}, 82 \%$ of the isolated fungal pathogens from date palm roots is known to be F. solani [5]. All previously mentioned reports are in agreement with the findings of the current study; however, no reports have linked any Fusarium spp. as the causal agent of SDS on date palm in the UAE. Therefore, an investigation of the causal agents of SDS on date palm and the remedy of this disease has to be done.

Due to the drying manner of fronds that displayed similar symptoms and disease severity of Bayoud (Fusarium wilt) as in North Africa [38,39], molecular diagnostic techniques using PCR [28] can eliminate the occurrence of Bayoud disease. Here, we confirm that there is no Bayoud disease and the fungus, F. oxysporum f. sp. albedinis, does not exist in the UAE. In view of the fact that three Fusarium spp., F. oxysporum f. sp. cumini (Prasad \& Patel), F. proliferatum (Matsushima) Nirenberg and F. solani (Martius) Saccardo [24-26] were isolated from root tissues of infested date palm trees showing SDS symptoms. Our cultural, morphological, and molecular phylogenetic analyses revealed that $F$. oxysporum f. sp. cumini DSM 106834, F. proliferatum DSM 106835, and F. solani DSM 106836 were the potential isolates associated with SDS on date palm in the UAE. Microscopic examinations of the hyphal and conidial morphology of these isolates were consistent with those previously reported [40-42]. In this study, individual sequences generated from the three isolates were compared with those maintained in the National Center for Biotechnology information (NCBI; www.ncbi.nlm.nih.gov) and relevant sequences were included in the subsequent phylogenetic inference. Phylogenetic congruencies of the single gene set ITS/TEF1- $\alpha$, clustered Fusarium isolates in three different clades corresponding to F. oxysporum, F. proliferatum, and F. solani. These isolates were further selected for pathogenicity assays.

Although there are few reports about the antagonistic effects of multiple Fusarium spp. on plants [43]; many others have shown synergistic effects [44,45]. The four Fusarium spp., F. graminearum, F. culmorum, F. poae, and F. sporotrichioides, causing foot and crown rot diseases on wheat (Triticum aestivum L.) have been reported to be more virulence when together [45]. Given the evidence for an arsenal of virulence factors of Fusarium spp., we hypothesized that interactions of the three species would lead to additive effects in pathogenicity on date palm. It is likely that synergism among multiple pathogens leads to more severity in disease symptoms than an individual pathogen [44]. Pathogenicity assays and DSI scores on healthy date palm seedlings inoculated with either F. oxysporum or F. proliferatum in the greenhouse did not provide evidence that these isolates cause SDS. This does not rule out the possibilities that these isolates may lead to minor disease symptoms, symptoms appearing at later stages of infection, or causing diseases under certain environmental conditions. Weather conditions are important parameters determining the production of mycotoxins such as deoxynivalenol by Fusarium spp. to cause diseases in plants [46]. After analyzing the morphological phenotypes amongst the isolates, no significant difference was found in the DSI between seedlings inoculated with F. solani vs. the three combined Fusarium spp. This suggests that $F$. solani is most probably the Fusarium species that plays a major role in establishing the SDS in date palm plantation in the UAE.

Because immediate and appropriate management for this destructive disease was highly required, we aimed to search for a cost-effective solution for the potential risk of SDS in the UAE. For that purpose, this research was further extended to evaluate systemic and non-systemic fungicides to potentially control the pathogen in vitro as well as in the greenhouse. In our efforts to find a successful fungicide to inhibit $F$. solani, we first tested the efficacy of three fungicides, Baiclean ${ }^{\circledR}$, Uniform ${ }^{\circledR}$ and Cidely ${ }^{\circledR}$ Top under in vitro conditions. Although all tested chemical treatments inhibited mycelial 
growth of $F$. solani in the controlled laboratory experiments, the systemic fungicide, Cidely ${ }^{\circledR}$ Top (difenoconazole and cyflufenamid), was the most effective chemical at a concentration of $250 \mathrm{ppm}$ (Figure 5). Similarly, Cidely ${ }^{\circledR}$ Top has also proven to be effective against a number of pathogens such $T$. punctulata and L. theobromae [33,47]. Other systemic fungicides, such as Bavistin D.F. (Carbendazim), have been reported to suppress F. solani and F. mangiferae [10,48,49].

Despite there is a body of evidences that the non-selective use of chemicals poses a perceived risk to human health and adverse effects to the environment [50], chemicals are still widespread to limit the damage on crops [51]. This is because of the ease of use, effectiveness, fast activity, and relatively low cost. Searching for eco-friendly strategies is crucial to control diseases in crops and reduce growth of pathogens. For example, IDM combines two or more antagonistic strategies of horticultural practices, fungicides, BCA and natural compounds [47,52,53]. To date, research is limited on the effectiveness of fungicide treatment to manage SDS because of the unpredictable nature of the disease [54]. Performances of the same treatments under similar laboratory-greenhouse-field studies are rare in plant science.

Our data demonstrated that Cidely ${ }^{\circledR}$ Top inhibited F. solani at $250 \mathrm{ppm}$ by affecting hyphal development, septum formation and cytoplasmic integrity. In addition, conidial formation of the fungal pathogen was also altered. In general, Cidely ${ }^{\circledR}$ Top was highly effective in reducing the pathogenic activities of $F$. solani. Similar to the in vitro observations, Cidely ${ }^{\circledR}$ Top showed a significant reduction in disease symptoms in relation to the conidia counts in Cidely ${ }^{\circledR}$ Top-treated seedlings at $25 \mathrm{dpt}$ in the greenhouse trials (Figure 6). This indicates that Cidely ${ }^{\circledR}$ Top can be considered as a candidate fungicide for the management of $F$. solani-affected date palm trees. The result obtained for Cidely ${ }^{\circledR}$ Top seems to be in agreement with previous findings that this fungicide inhibits the growth of plant pathogens [33,47]. Cidely ${ }^{\circledR}$ Top, on the other hand, does not have a retarded effect on F. magniferae [48]. This could be attributed to many factors such as fungicide application methods, growth conditions and the nature of fungal species. The fungicide Cidely ${ }^{\circledR}$ Top contains the active substance, cyflufenamid, which is known to act in the developmental stages of mycelia and spores, which may possibly contribute to the increased extent of inhibition of $F$. solani. To the best of our knowledge, this is the first study relating the assessment of Cidely ${ }^{\circledR}$ Top on date palm trees infected with F. solani. Farmers in the UAE, the region and other date production areas suffering from this devastating disease will directly benefit from this study. Thus, the same fungicide was fairly known to be successful on other pathogenic fungi including T. punctulata on date palm and L. theobromae on mango [33,47]. Therefore, a future field experiment has to be deployed to test the efficacy of Cidely ${ }^{\circledR}$ Top in 'real' infected date palm orchards.

In this regard, we identified $F$. solani as the main causal pathogen of SDS on date palm in the UAE. We concluded that Cidely ${ }^{\circledR}$ Top was a favorable chemical means to inhibit the growth of the pathogen on date palm. Future directions for seeking environmentally-friendly applications i.e., IDM to manage SDS in date palm is on our priorities. Our long term goal is to achieve the protection of date palm health and its productivity and improve environment sustainability. Conventional breeding, plant biotechnology, and modern molecular tools [53] could also generate breakthroughs for the production of new resistant varieties to SDS.

\section{Materials and Methods}

\subsection{Isolation, Purification, and Culture Maintenance}

Fusarium spp. isolated from the roots of surface sterilized symptomatic date palm trees obtained from Al Wagan area in Al Ain city (Abu Dhabi Emirate; Latitude/Longitude: 24.19/55.76) were studied in this research. No specific permissions were required for the location. Sections were made of the diseased tree roots and the pathogens were isolated. The isolated fungi were maintained on PDA (Lab M Limited, Lancashire, UK) plates supplemented with $25 \mathrm{mg} / \mathrm{L}$ penicillin-streptomycin (Sigma-Aldrich Chemie GmbH, Taufkirchen, Germany) and under growth conditions at pH 6.0 and 
temperature $25{ }^{\circ} \mathrm{C}$. After seven days of incubation, the mycelia growing from the plated tissues were sub-cultured on fresh PDA and lastly purified by using hyphal-tip isolation technique [55]. Later, sub-culturing on fresh slants was done at biweekly intervals to maintain the stock cultures and preserved at $25^{\circ} \mathrm{C}$. Mycelia and conidia were observed using Nikon-Eclipse 50i light microscope (Nikon Instruments Inc., NY, USA) to characterize different fungal structures. A culture of the identified Fusarium spp.: F. oxysporum f. sp. cumini (Prasad \& Patel), F. proliferatum (Matsushima) Nirenberg and F. solani (Martius) Saccardo [24-26], has been deposited in Leibniz-Institute DSMZ-Deutsche Sammlung von Mikroorganismen und Zellkulturen GmbH (Braunschweig, Germany) under the collection numbers DSM 106834, DSM 106835, and DSM 106836, respectively.

\subsection{DNA Isolation, $P C R$, and Sequencing}

DNA of the pathogen isolated from infected root tissues was extracted from mycelium cultured for 14 days on PDA plates at $25^{\circ} \mathrm{C}$. DNA extractions were performed using the plant/fungi DNA isolation kit (Norgen Biotek Corp., Thorold, Canada). PCR reactions contained reaction buffer, $2.2 \mathrm{mM} \mathrm{MgCl}$, $200 \mu \mathrm{M}$ of each dNTP, 2.5 unit of Taq DNA polymerase, a 30-ng DNA template and 50 pmol of each primer, making to a final volume of $50 \mu \mathrm{L}$. PCR was set for 32 cycles; each cycle consisted of: $94{ }^{\circ} \mathrm{C}$ for $1 \mathrm{~min}$; $58^{\circ} \mathrm{C}$ for $1 \mathrm{~min} ; 72{ }^{\circ} \mathrm{C}$ for $1 \mathrm{~min}$. For the three Fusarium spp., PCR amplified target regions of ITS using ITS1 and ITS4 primers [56], 28S rDNA using LRoR and LR5 [57], TEF1- $\alpha$ using EF1-728F and EF1-986R [58], and $\beta$-tubulin using Bt1a and Bt1b [59]. In addition, pFalb11 and pFalb28 belonging to F. oxysporum $\mathrm{f}$. sp. albedinis were also amplified. All primer sequence sets can be found in Table S1.

\subsection{Phylogenetic Analysis}

For the analysis of the phylogenetic placement of the fungal isolate the sequences of ITS /LSU rDNA and TEF1- $\alpha$ genes were used as single gene set and concatenated two-gene set, ITS /TEF1- $\alpha$. The obtained ITS/LSU (accession numbers MH055398, MH055399, and MH055400) TEF1- $\alpha$ (accession numbers MH087478, MH087479, and MH087480) sequences were deposited in GenBank for $F$. oxysporum, F. proliferatum, and F. solani, respectively, and were further combined for constructing the phylogenetic tree against other Fusarium spp. database managed by NCBI.

The ITS/TEF1-a sequences were aligned with sequences retrieved from GenBank, representing isolates that belong to about 30 species of the genus Fusarium [12,33]. All sequences were compared and aligned and ML analyses were performed for estimation of the phylogenetic tree [60]. Phylogenetic trees were constructed and validated with a statistical support of the branches with 100 bootstrap resamples. The isolates used in the dendrogram were: F. proliferatum, F. conentricum, F. verticillioides, F. pseudocircinatum, F. nygamai, F. acutatum, F. udum, F. sacchari, F. oxysporum, F. foetens, F. commune, F. redolens, F. lacertarum, F. meridionale, F. graminearum, F. austroamericanum, F. culmorum, F. sporotrichioides, F. brachygibbosum, F. concolor, F. lateritium, F. solani, other Fusarium spp. and Nectriaceae spp.

\subsection{Disease Assays and Pathogenicity Tests}

Fungal isolates grown in PDA plates as described above were prepared for conidial suspension for inoculation purposes. The inoculums were prepared by adding $10 \mathrm{~mL}$ of sterile distilled water to the 14-day-old fungal culture and scrapped by sterilized scraper. The harvested conidial solution was poured into a $50 \mathrm{~mL}$ Falcon tube after filtering the solution twice through sterile Miracloth. The conidial concentration was determined using hemocytometer (Agar Scientific Limited, UK) and adjusted to $1 \times 10^{6}$ conidia $/ \mathrm{mL}$ according to [61].

Pathogenicity tests were conducted using Koch's postulates to confirm the Fusarium spp. as the causal agent of SDS of date palm orchard. Six-month-old date palm seedlings (cv. Barhi), obtained from the Date Palm Development Research Unit/UAEU (DPDRU) and showing no disease symptoms, were used. The Fusarium spp. used were the representative of isolates of F. oxysporum DSM 106834, F. proliferatum DSM 106835, and F. solani DSM 106836, which were successfully isolated and identified from SDS of date palm orchard. Seedlings $(n=12)$ were inoculated with $10 \mathrm{~mL}$ of inoculum on roots that were separately 
dipped for one hour in the inoculum suspension of each Fusarium spp. or altogether. The control plants were dipped in $10 \mathrm{~mL}$ of sterile distilled water. The inoculated seedlings were covered with transparent polyethylene sheet for $72 \mathrm{~h}$. Seedlings in 1.5-L plastic pots containing sterilized soil mixture (3:2:1 v/v ratio of top soil-peatmoss-sand) were grown randomly on the bench in a greenhouse with temperature of $25^{\circ} \mathrm{C}$ and $60 \% \mathrm{RH}$, and watered two times weekly. Disease severity index on inoculated seedlings was recorded for SDS symptoms at 10 and $35 \mathrm{dpi}$ using a scale of 0-5: $0=$ no apparent symptoms, $1=1-10 \%$ necrotic or white area in leaves or rotting in roots, $2=11-25 \%, 3=26-50 \%, 4=51-75 \%$, and $5=76-100 \%$ [62]. All experiments were independently repeated three times with similar results.

To satisfy Koch's postulates, pieces of inoculated root tissues were removed from seedlings showing diseases symptoms at $35 \mathrm{dpi}$, surface sterilized with $70 \%$ ethanol and plated on PDA. Plates were incubated at $25 \pm 2{ }^{\circ} \mathrm{C}$ and the subsequent growth was recorded.

\subsection{Evaluation of Fungicides against F. solani}

The fungicide experiment was carried out as previously described $[4,33,47]$. These fungicides selected were Baiclean ${ }^{\circledR}$ (Oligosaccharin; Baico, Beijing Multigrass Formulation Co., China), Uniform ${ }^{\circledR}$ (Azoxystrobin and Metalaxyl-M; Syngenta, USA) and Cidely ${ }^{\circledR}$ Top 125/15 DC (Difenoconazole and Cyflufenamid; Syngenta). Each of the obtained fungicide was dissolved in water to a final concentration of $0,25,75,125,250,500$, and 1000 ppm, and then introduced into sterilized PDA at $25^{\circ} \mathrm{C}$. To inhibit the bacterial growth, penicillin-streptomycin antibiotics was also introduced. The solution was swirled to attain homogenization status. The mixtures were dispensed aseptically into sterile Petri dishes. A sterile cork-borer (8-mm in diameter) was used to introduce the tested pathogen onto the medium without fungicide (control) or with fungicide (treatment). Cultures were incubated at $25{ }^{\circ} \mathrm{C}$ for 10 days and radial growth measurements were recorded daily. The percentage of the mycelial growth was measured and growth inhibition was calculated according to the equation

$$
\% \mathrm{Mi}=(\mathrm{Mc}-\mathrm{Mt}) / \mathrm{Mc} \times 100 \%
$$

where; $\mathrm{Mi}=$ Inhibition of the mycelial growth; $\mathrm{Mc}=$ colony diameter (in $\mathrm{mm}$ ) of control set; and $\mathrm{Mt}=$ colony diameter (in $\mathrm{mm}$ ) of the target fungus on the medium with fungicide.

An in vivo evaluation of Cidely ${ }^{\circledR}$ Top, which is the most effective fungicide, was also carried out on six-month-old date palm seedlings (cv. Barhi) grown in 1.5-L plastic pots containing sterilized soil mixture under greenhouse conditions, as described above. Seedlings were previously inoculated with $10 \mathrm{~mL}$ of inoculum on roots that were separately dipped for one hour in the inoculum suspension of F. solani, and were further kept in the greenhouse at $25^{\circ} \mathrm{C}$ for $10 \mathrm{dpi}$ (until disease symptoms were evident). Similar to inoculated seedlings, control plants were dipped in $10 \mathrm{~mL}$ of sterile distilled water. $F$. solani-inoculated plants were then either sprayed with 250 ppm of Cidely ${ }^{\circledR}$ Top fungicide or with sterilized distilled water (F. solani). To estimate the number of conidia in the greenhouse experiment, conidia counts of known weight of affected tissues was homogenized in $5 \mathrm{~mL}$ of water and the suspended material was assessed using haemocytometer. For all inoculated seedlings, DSI was recorded for SDS symptoms at 7 and $25 \mathrm{dpt}$ (corresponding to 17 and $35 \mathrm{dpi}$ with F. solani) using a scale of $0-5$, as described above.

\subsection{Statistical Analysis}

For the in vitro evaluation of fungicides against Fusarium spp., eight plates for each treatment were used. For the DSI of the pathogenicity of Fusarium spp. and Cidely ${ }^{\circledR}$ Top treatment tests against F. solani in the greenhouse, three replicates for each treatment were examined and recorded. Data represent the mean \pm SD from a minimum of 12 plants per replicate. Analysis of Variance (ANOVA) and Duncan's multiple range test were performed to determine the statistical significance at $p<0.05$. All experiments were independently repeated three times with similar results. Similar results were obtained in each replicate. SAS Software version 9 was used for all statistical analyses performed [63]. 
Supplementary Materials: Supplementary materials can be found at http:/ /www.mdpi.com/1422-0067/20/4/ 923/s1.

Author Contributions: K.A.E.-T. and S.F.A. conceived and designed the experiments; K.J.A., E.E.S., A.S., A.A.A., and M.A.A. performed the experiments; K.A.E.-T. and S.F.A. analyzed the data; K.A.E.-T. and S.F.A. contributed reagents/materials/analysis tools; K.A.E.-T. and S.F.A. wrote the paper. All authors have read and approved the manuscript.

Funding: This research was funded by "Khalifa Center for Biotechnology and Genetic Engineering-UAEU, grant number 31R081" and "The UAEU Program for Advanced Research, grant number 31S255".

Conflicts of Interest: The authors declare no conflict of interest.

\section{References}

1. Hamad, I.; AbdElgawad, H.; Al Jaouni, S.; Zinta, G.; Asard, H.; Hassan, S.; Hegab, M.; Hagagy, N.; Selim, S. Metabolic analysis of various date palm fruit (Phoenix dactylifera L.) cultivars from Saudi Arabia to assess their nutritional quality. Molecules 2015, 20, 13620-13641. [CrossRef] [PubMed]

2. Food and Agriculture Organization of the United Nations (FAO). Date Palm Production; FAOSTAT Database; FAO: Rome, Italy, 2016.

3. Abdullah, S.K.; Lopez Lorca, L.V.; Jansson, H.B. Diseases of date palms (Phoenix dactylifera L.). Basrah J. Date Palm Res. 2010, 9, 1-44.

4. Saeed, E.E.; Sham, A.; El-Tarabily, K.A.; Abu Elsamen, F.; Iratni, R.; AbuQamar, S.F. Chemical control of dieback disease on date palm caused by the fungal pathogen, Thielaviopsis punctulata, in United Arab Emirates. Plant Dis. 2016, 100, 2370-2376. [CrossRef] [PubMed]

5. Alhammadi, M.S.; Al-Shariqi, R.; Maharachchikumbura, S.; Al-Sadi, A.M. Molecular identification of fungal pathogens associated with date palm root diseases in the United Arab Emirates. J. Plant Pathol. 2018, 99, 1-7.

6. Abdalla, M.Y.; AI-Rokibah, A.; Moretti, A.; Mule, G. Pathogenicity of toxigenic Fusarium proliferatum from date palm in Saudi Arabia. Plant Dis. 2000, 84, 321-324. [CrossRef]

7. Armengol, J.; Moretti, A.; Perrone, G.; Vicent, A.; Bengoechea, J.A.; García-Jiménez, J. Identification, incidence and characterization of Fusarium proliferatum on ornamental palms in Spain. Eur. J. Plant Pathol. 2005, 112, 123-131. [CrossRef]

8. Sarhan, A.R.T. A study on the fungi causing decline of date palm trees in middle of Iraq. In Proceedings of the Second International Conference on Date Palm, Al Ain, UAE, 25-27 March 2001; pp. 424-430.

9. Mansoori, B.; Kord, H. Yellow death: A disease of date palm in Iran caused by Fusarium solani. J. Phytopathol. 2006, 154, 125-127. [CrossRef]

10. Maitlo, W.A.; Markhand, G.S.; Abul-Soad, A.A.; Lodhi, A.M.; Jatoi, M.A. Chemcial control of sudden decline disease of date palm (Phoenix dactylifera L.) in Sindh, Pakistan. Pak. J. Bot. 2013, 45, 7-11.

11. Sabet, K.K.; Ghanem, G.A.; Rashed, M.F.; Allam, L.A. Fungal infection of date palm tissue culture. J. Agric. Sci. Mansoura Univ. 2006, 31, 735-745.

12. El Hassni, M.; El Hadrami, A.; Daayf, F.; Chérif, M.; Barka, E.; El Hadrami, I. Biological control of bayoud disease in date palm: Selection of microorganisms inhibiting the causal agent and inducing defense reactions. Environ. Exp. Bot. 2007, 59, 224-234. [CrossRef]

13. Tantaoui, A.; Ouinten, M.; Geiger, J.-P.; Fernandez, D. Characterization of a single clonal lineage of Fusarium oxysporum f. sp. albedinis causing Bayoud disease of date palm in Morocco. Phytopathology 1996, 86, 787-792.

14. Shabani, F.; Kumar, L. Risk levels of invasive Fusarium oxysporum f. sp. in areas suitable for date palm (Phoenix dactylifera) cultivation under various climate change projections. PLoS ONE 2013, 8, e83404. [CrossRef]

15. Okungbowa, F.I.; Shittu, H.O. Fusarium wilts: An overview. Environ. Res. J. 2012, 6, 83-102.

16. Saremi, H.; Okhovvat, S.M.; Ashrafi, S.J. Wilting of date palm branches by Fusarium oxysporum in south of Iran and its control managements with soil solarization method. Commun. Agric. Appl. Biol. Sci. 2007, 72, 831-837.

17. Bokhary, H.A. Seed-borne fungi of date-palm, Phoenix dactylifera L. from Saudi Arabia. Saudi J. Biol. Sci. 2010, 17, 327-329. [CrossRef] 
18. Maitlo, W.A.; Markhand, G.S.; Abul-Soad, A.A.; Lodhi, A.M.; Jatoi, M.A. Fungi associated with sudden decline disease of date palm (Phoenix dactylifera L.) and its incidence at Khairpur, Pakistan. Pak. J. Bot. 2016, 26, 65-71.

19. Abul-Soad, A.A.; Mahdi, S.M.; Markhand, G.S. Date Palm Status and Perspective in Pakistan. In Date Palm Genetic Resources and Utilization; Al-Khayri, J., Jain, S., Johnson, D., Eds.; Springer: Dordrecht, The Netherlands, 2015; pp. 153-205.

20. El Kinany, S.; Faggroud, M.; Ouahmane, L.; El Hilali, R.; Haggoud, A.; Bouamri, R. Effect of organic fertilizer and commercial arbuscular mycorrhizal fungi on the growth of micropropagated date palm cv. Feggouss. J. Saudi Soc. Agric. Sci. 2018. [CrossRef]

21. Salim, H.A.; Hassan, K.A.; Ishak, H.S.; Hussein, A.A.; Gab, A. Control of wilt disease (Sudden Decline Syndrome) on date palms in Iraq. Am. Multidis. Int. Res. J. 2015, 2, $29-33$.

22. Abul-Soad, A.A.; Maitlo, W.A.; Markhand, G.S.; Mahdi, S.M. Date palm wilt disease (sudden decline syndrome) in Pakistan, symptoms and remedy. Blessed Tree 2011, 3, 38-43.

23. Razdan, V.; Sabitha, M. Integrated disease management: Concepts and practices. In Integrated Pest Management: Innovation-Development Process; Peshin, R., Dhawan, A.K., Eds.; Springer: Dordrecht, The Netherlands, 2009; pp. 369-389.

24. Patel, P.N.; Prasad, N.; Mathur, R.L.; Mathur, B.L. Fusarium wilt of cumin. Curr. Sci. 1957, 26, $181-182$.

25. Nirenberg, H. Unterscuchungen "zber die morphologische and biologische. Differenzierung in der Fusarium-Section Liseola. Mitteilungen der Biologischen Budesanstalt f 'or Land- und Forstwirtschaft 1976, 169, 1-117.

26. Saccardo, P.A. Fungi Veneti novi vel critici v. mycologiae Veneti addendi. Series XII. Michelia 1881, 2, $241-301$.

27. Alves, A.; Crous, P.W.; Correia, A.; Phillips, A.J.L. Morphological and molecular data reveal cryptic speciation in Lasiodiplodia theobromae. Fungal Divers. 2008, 28, 1-13.

28. Fernandez, D.; Ouinten, M.; Tantaoui, A.; Geiger, J.P.; Daboussi, M.J.; Langin, T. Fot 1 insertions in the Fusarium oxysporum f. sp. albedinis genome provide diagnostic PCR targets for detection of the date palm pathogen. Appl. Environ. Microbiol. 1998, 64, 633-636.

29. Watanabe, M. Molecular phylogeny and identification of Fusarium species based on nucleotide sequences. Mycotoxins 2013, 63, 133-142. [CrossRef]

30. Saleh, A.A.; Sharafaddin, A.H.; El-Komy, M.H.; Ibrahim, Y.E.; Hamad, Y.K.; Molan, Y.Y. Fusarium species associated with date palm in Saudi Arabia. Eur. J. Plant Pathol. 2017, 148, 367-377. [CrossRef]

31. O'Callaghan, M. Microbial inoculation of seed for improved crop performance: Issues and opportunities. Appl. Microbiol. Biotechnol. 2016, 100, 5729-5746. [CrossRef]

32. Zaid, A.; de Wet, P.F.; Djerbi, M.; Oihabi, A. Chapter XII: Diseases and pests of date palm. In Date Palm Cultivation; Zaid, A., Ed.; Plant Production and Protection Paper No. 156; FAO: Rome, Italy, 2002.

33. Saeed, E.E.; Sham, A.; AbuZarqa, A.; Al Shurafa, K.; Al Naqbi, T.S.; Iratni, R.; El-Tarabily, K.A.; AbuQamar, S.F. Detection and management of mango dieback disease in the United Arab Emirates. Int. J. Mol. Sci. 2017, 18, 2086. [CrossRef]

34. El-Deeb, H.M.; Lashin, S.M.; Arab, Y.A. Distribution and pathogenesis of date palm fungi in Egypt. Acta Hortic. 2007, 736, 421-429. [CrossRef]

35. Abdullah, S.K.; Asensio, L.; Monfort, E.; Gomez-Vidal, S.; Salinas, J.; Lopez Lorca, L.V.; Jansson, H.B. Incidence of the two date palm pathogens, Thielaviopsis paradoxa and T. punctulata in soil from date palm plantations in Elx, south-east Spain. J. Plant Prot. Res. 2009, 49, 276-279.

36. Hameed, M.A. Inflorescence rot disease of date palm caused by Fusarium proliferatum in Southern Iraq. Afr. J. Biotechnol. 2012, 11, 8616-8621.

37. Rashed, M.F.; Abdel Hafeez, N.E. Decline of date palm trees in Egypt. In Proceedings of the Second International Conference on Date Palm, Al Ain, UAE, 25-27 March 2001; pp. 401-407.

38. Killian, C.; Maire, R. Le bayoud maladie du dattier. Bull. Soc. Hist. Na. Afr. 1930, 21, 89-101.

39. Djerbi, M. Bayoud disease in North Africa, history, distribution, diagnosis and control. Date Palm J. 1982, 1, 153-197.

40. Nawade, B.; Talaviya, J.R.; Vyas, U.M.; Jadeja, K.B.; Golakiya, B.A. Diversity analysis among Fusarium oxysporum F. sp. cumini isolates using ISSR markers, spore morphology and pathogenicity. Int. J. Curr. Microbiol. App. Sci. 2017, 6, 79-87. 
41. Adame-García, G.; Rodríguez-Guerra, R.; Iglesias-Andreu, L.G.; Ramos-Prado, J.M.; Luna-Rodríguez, M. Molecular identification and pathogenic variation of Fusarium species isolated from Vanilla planifolia in Papantla Mexico. Bot. Sci. 2015, 93, 669-678. [CrossRef]

42. Abd-Elsalam, K.A.; Youssef, K.; Almoammar, H. First morphogenetic identification of Fusarium solani isolated from orange fruit in Egypt. FYTON 2015, 84, 128-131.

43. Lemanceau, P.; Bakker, P.A.H.M.; De Kogel, W.J.; Alabouvette, C.; Schippers, B. Antagonistic effect of nonpathogenic Fusarium oxysporum Fo47 and Pseudobactin 358 upon pathogenic Fusarium oxysporum f. sp. dianthi. Appl. Environ. Microbiol. 1993, 59, 74-82.

44. Lamichhane, J.R.; Venturi, V. Synergisms between microbial pathogens in plant disease complexes: A growing trend. Front. Plant Sci. 2015, 6, 385. [CrossRef]

45. Kuzdraliński, A.; Nowak, M.; Szczerba, H.; Dudziak, K.; Muszyńska, M.; Leśniowska-Nowak, J. The composition of Fusarium species in wheat husks and grains in south-eastern Poland. J. Integr. Agric. 2017, 16, 60345-60347. [CrossRef]

46. Landschoot, S.; Waegeman, W.; Audenaert, K.; Vandepitte, J.; Baetens, J.M.; De Baets, B.; Haesaert, G. An empirical analysis of explanatory variables affecting Fusarium head blight infection and deoxynivalenol content in wheat. J. Plant Pathol. 2012, 94, 135-147.

47. Saeed, E.E.; Sham, A.; Salmin, Z.; Abdelmowla, Y.; Iratni, R.; El-Tarabily, K.A.; AbuQamar, S.F. Streptomyces globosus UAE1, a potential effective biocontrol agent for black scorch disease in date palm plantations. Front. Microbiol. 2017, 8, 1455. [CrossRef]

48. Iqbal, Z.; Pervez, M.A.; Ahmad, S.; Iftikhar, Y.; Yasin, M.; Nawaz, A.; Ghazanfar, M.U.; Dasti, A.A.; Saleem, A. Determination of minimum inhibitory concentrations of fungicides against fungus Fusarium mangiferae. Pak. J. Bot. 2010, 42, 3525-3532.

49. Bhanumathi, A.; Ravishankar, R.V. Leaf blight of Azadirachta indica and its in vitro management. Afr. J. Agric. Res. 2007, 2, 53-543.

50. Aktar, M.W.; Sengupta, D.; Chowdhury, A. Impact of pesticides use in agriculture: Their benefits and hazards. Interdiscip. Toxicol. 2009, 2, 1-12. [CrossRef]

51. Ganesan, K.; Raza, S.K.; Vijayaraghavan, R. Chemical warfare agents. J. Pharm. Bioallied Sci. 2010, 2, $166-178$. [CrossRef]

52. Kamil, F.H.; Saeed, E.E.; El-Tarabily, K.A.; AbuQamar, S.F. Biological control of mango dieback disease caused by Lasiodiplodia theobromae using streptomycete and non-streptomycete actinobacteria in the United Arab Emirates. Front Microbiol. 2018, 9, 829. [CrossRef]

53. AbuQamar, S.F.; Moustafa, K.; Tran, L.S. Mechanisms and strategies of plant defense against Botrytis cinerea. Crit. Rev. Biotechnol. 2017, 37, 263-275. [CrossRef]

54. Weems, J.D.; Haudenshield, J.S.; Bond, J.P.; Hartman, G.L.; Ames, K.A.; Bradley, C.A. Effect of fungicide seed treatments on Fusarium virguliforme infection of soybean and development of sudden death syndrome. Can. J. Plant Pathol. 2015, 37, 435-447. [CrossRef]

55. Kirsop, B.E.; Doyle, A. Maintenance of Microorganisms and Cultured Cells, a Manual of Laboratory Methods, 2nd ed.; Academic Press: London, UK, 1991.

56. White, T.J.; Bruns, T.; Lee, S.; Taylor, J. Amplificatin and direstc sequencing of fungal ribosomal RNA genes for phylogenetics. PCR Protoc. 1990, 91, 315-322.

57. Schoch, C.L.; Seifert, K.A.; Huhndorf, S.; Robert, V.; Spouge, J.L.; Levesque, C.A.; Chen, W. Fungal Barcoding Consortium. Nuclear ribosomal internal transcribed spacer (ITS) region as a universal DNA barcode marker for Fungi. Proc. Natl. Acad. Sci. USA 2012, 109, 6241-6246. [CrossRef]

58. Carbone, I.; Kohn, L.M. A method for designing primer sets for speciation studies in filamentous ascomycetes. Mycologia 1999, 91, 553-555. [CrossRef]

59. Orbach, M.J.; Porro, E.B.; Yanofsky, C. Cloning and characterization of the gene for $\beta$-tubulin from a benomyl-resistant mutant of Neurospora crassa and its use as a dominant selectable marker. Mol. Cell. Biol. 1986, 6, 2452-2461. [CrossRef]

60. Tamura, K.; Stecher, G.; Peterson, D.; Filipski, A.; Kumar, S. MEGA6: Molecular evolutionary genetics analysis version 6.0. Mol. Biol. Evol. 2013, 30, 2725-2729. [CrossRef]

61. Elhassan, A.M. Isolation, identification and characterization of Fusarium oxysporum, the causal agent of Fusarium wilt disease of date palm Phoeniex dactylifera L. in Northern State Sudan. Int. J. Curr. Microbiol. App. Sci. 2016, 5, 381-386. [CrossRef] 
62. Molan, Y.Y.; Al-Obeed, R.S.; Harhash, M.M.; El-Husseini, S. Decline of date-palm offshoots with Chalara paradoxa in Riyadh region. J. King Saud Univ. 2004, 16, 79-86.

63. SAS Institute. The SAS System for Windows; Release 9.0; SAS Institute: Cary, NC, USA, 2002.

(C) 2019 by the authors. Licensee MDPI, Basel, Switzerland. This article is an open access article distributed under the terms and conditions of the Creative Commons Attribution (CC BY) license (http:/ / creativecommons.org/licenses/by/4.0/). 